\title{
Janina Kosman
}

Archiwum Państwowe w Szczecinie, Szczecin, Polska

jkosman@szczecin.ap.gov.pl

(iD) 0000-0003-1514-4712

https://doi.org/10.33077/uw.25448730.zbkh.2021.665

\section{Działalność szkolnego Towarzystwa Czytelniczego w Gimnazjum Mariackim w Szczecinie w XIX i pierwszych dekadach XX w. Z dziejów kultury książki w dawnym Szczecinie}

\author{
The activity of the School Reading Society \\ at St. Mary's Gymnasium in Szczecin \\ in the $19^{\text {th }}$ and early $20^{\text {th }}$ century.
}

A contribution to the history of book culture in old Szczecin

\begin{abstract}
St. Mary's Gymnasium in Szczecin, one of the oldest high schools in the city, has a rich history. An interesting trend in the school's history is represented by the school's interest groups. Among the oldest and most numerous are choirs and recitation groups, some dating back to the $18^{\text {th }}$ century. Other groups, with a specific profile and programme, also developed systematically. In the $19^{\text {th }}$ century reading societies (Leseverein) were particularly active in the gymnasium. The tradition of these societies continued into the $20^{\text {th }}$ century. It fits into the broader context of Szczecin's school theatres. Their activities can be traced on the basis of information contained in printed school reports, which give the programme of activities of school interest groups and specify their participation in school calendar celebrations. Valuable material are the archives stored in the State Archives in Szczecin concerning St. Mary's Gymnasium, including documents created by members of the reading society.
\end{abstract}

Key words: $19^{\text {th }}-20^{\text {th }}$ century education - St. Mary's Gymnasium in Szczecin - reading - school libraries - State Archives in Szczecin

Słowa kluczowe: Szkolnictwo XIX-XX w. - czytelnictwo - biblioteki szkolne - Archiwum Państwowe w Szczecinie 
Szkoły, oprócz swoich zasadniczych funkcji nauczania i wychowania, były też środowiskiem odzwierciedlającym różne aspekty kultury książki. Placówki te niejednokrotnie stawały się znaczącymi ośrodkami lokalnego życia kulturalnego i artystycznego. Godne podkreślenia są rozmaite inicjatywy szkolne pozwalające na realizowanie odpowiedniego modelu edukacji ( $\mathrm{w}$ omawianym przypadku humanistycznego). Znaczące miejsce spośród nich należy przyznać aktywności uczniowskiej przejawiającej się na rozmaitych polach. Należało tutaj m.in. uczestnictwo młodzieży w kołach zainteresowań, łączące elementy edukacji szkolnej i pozaszkolnej. Przedmiotem niniejszego omówienia jest jedna z form takiej właśnie działalności uczniów w szczecińskim Gimnazjum Mariackim, szkole legitymującej się najstarszą w mieście tradycją. Mowa o Towarzystwie Czytelniczym (Leseverein), upowszechniającym aktywne czytelnictwo i organizującym inscenizacje teatralne.

Ze zorganizowaną formą ruchu czytelniczego, czyli towarzystwami czytelniczymi (niem. Lesegesellschaft, Leseverein) mamy do czynienia już w okresie oświecenia. Organizacje te proponowały swoim członkom bieżącą prasę i periodyki naukowe, umożliwiały też lekturę książek w ramach stowarzyszeniowych księgozbiorów, gromadzonech ze środków pochodzących ze składek członkowskich ${ }^{1}$. Towarzystwa czytelnicze powstawały również w szkołach, aczkolwiek miały tu do odegrania inną rolę. Na przykładzie Leseverein działającego w XIX i pierwszych dekadach XX w. w Gimnazjum Mariackim w Szczecinie² możemy prześledzić działalność typowego

1 Zob. R. Engelsing, Der Bürger als Leser, Lesergeschichte in Deutschland 1500-1800, Stuttgart 1974.

2 Początki szczecińskiego szkolnictwa sięgają średniowiecza. Przy ufundowanym przez księcia Barnima I kościele pw. Najświętszej Marii Panny powstał wówczas zakład nauczania powierzony opiece Kapituły NMP. Na długie lata stał się on centrum oświaty i nauki w mieście. Książęta pomorscy w 1543 r. spełnili obietnicę powołania w Szczecinie nowej szkoły czyli Pedagogium Książęcego. Placówka ta odgrywała ważną rolę w życiu umysłowym miasta. W XVII w., za czasów szwedzkich, Pedagogium zostało przekształcone w Gimnazjum Carolinum (Regium Gimnasium Carolinum). Szkoła, dobrze wyposażona i zorganizowana, pozostawała nadal w ścisłej zależności od prebend Kościoła Mariackiego. Nie ominęły jej jednak liczne kryzysy. W 1677 r. w czasie oblężenia Szczecina, budynek gimnazjum uległ zniszczeniu. Po przejęciu miasta przez Prusy nowe władze na początku XVIII w. przystąpiły do odnowy placówki. Kolejne uroczyste otwarcie zakładu nastąpiło w 1716 r. Powołane wówczas Gimnazjum Akademickie (Gimnasium Academicum) stało się główną placówką oświatową na Pomorzu. Pod koniec XVIII w. zaczęto na nowo rozważać wysuwany już wcześniej projekt połączenia Gimnazjum Akademickiego z Liceum Miejskim (Ratslyzeum), szkołą której tradycja sięgała początków XV w. Do fuzji obu placówek doszło w 1805 r. Połączonym szkołom nadano wówczas miano Królewskiego i Miejskiego Gimnazjum (Königliches und Stadtgymnasium). W 1868 r. szkoły ponownie rozdzielono. Z Królewskiego i Miejskiego Gimnazjum wydzielono Średnią Szkołę Miejską (Höhere Burgerschule) i szkołę o profilu humanistycznym pod dawną nazwą Gimnazjum Mariackiego. W tym kształcie placówka przetrwała do II wojny światowej. Zob. M. Wehrmann, Festschrift zum dreihundertfünfzigjährigen Jubiläum des Königlichen Marienstifts-Gymnasiums zu Stettin am 24. und 25. September 1894, Stettin 1894; Od Pedagogium Ksiązęcego do Gimnazjum Mariackiego. Z dziejów szkolnictwa półwyższego w Szczecinie do począt- 
szkolnego towarzystwa czytelniczego oraz zaobserwować wpływ, jaki wywierało na kształt szkolnej kultury.

Materiału do opracowania tematu dostarczają przede wszystkim drukowane sprawozdania szkolne, będące cennym źródłem do dziejów szkolnictwa w omawianym okresie. Na przestrzeni stuleci zmieniały one swoją formę i treści. Sprawozdania XIX i XX-wieczne zawierały m.in. oprócz szczegółowego zazwyczaj kalendarium wydarzeń szkolnych oraz stałego wykazu tematyki zajęć i nazwisk profesorów poszczególnych przedmiotów, częstokroć wyniki ich badań naukowych w formie rozpraw i dysertacji. Szczegółowych informacji dotyczących kółek zainteresowań, dostarczały następujące działy sprawozdań szkolnych: Chronik der Schule lub Schülerselbstverwaltung, Schülervereine. Dane tu zawarte pozwalają na wyodrębnienie poszczególnych kategorii kółek, programu działań, podejmowanych inicjatyw, liczby członków, obrazują wpływ wywierany na społeczność pozaszkolną, z którą placówki oświatowe łączyły rozmaite więzi. W sprawozdaniach pojawiają się też oświadczenia dyrektorów szkół odnoszące się do tego typu aktywności uczniów. W tych ostatnich nie brak emfatycznych wypowiedzi wskazujących, iż szkolne towarzystwa: „,mogą być czystym źródłem szlachetnych, młodzieńczych radości"33.

Aktywne uczestnictwo miało stwarzać zrzeszonej młodzieży warunki do nawiązywania przyjaźni, do integracji, wzbudzać poczucie lojalności, przyzwyczajać do parlamentarnych obyczajów i poszanowania wolności słowa ${ }^{44}$. Działalność szkolnych kół zainteresowań była na tyle dynamiczna, iż utworzyły one szczecińską federację towarzystw szkolnych (Kartellverband der Schulvereine) ${ }^{55}$.

Drukowane sprawozdania szkolne Gimnazjum Mariackiego jak już wspomniano są ważnym źródłem informacji na temat omawianego tu koła

ków XIX w., red. A. Borysowska, Szczecin 2018; Akademicki Szczecin. XVI-XXI wiek, red. P. Niedzielski, W. Tarczyński, Szczecin 2016.

3 „Jahresbericht 1911/1912 des Stettiner Stadtgymnasiums ehemaligen Ratslyceums” 1912, s. 150 .

4 Tamże. Informacje dotyczące szkolnych kółek zainteresowań odnajdujemy również w sprawozdaniach innych szkół szczecińskich, by przywołać Gimnazjum Króla Wilhelma (König-Wilhelmsgymnasium). Uczniowie jednej z klas powołali tu 18 VIII 1927 r. Leseverein, organizując cotygodniowe wieczory czytelnicze. Już w październiku podczas uroczystości upamiętniających 150. rocznicę urodzin Heinricha Kleista, członkowie towarzystwa przygotowali wybrane sceny ze sztuki tego twórcy „Rozbity dzban”. Zob. „Staatliches König- Wilhelmsgymnasium zu Stettin. Bericht über das Schuljahr 1927/1928" 1928, s. 16.

5 Z ramienia Gimnazjum Mariackiego do federacji tej należało pięć towarzystw: Leseverein, Paterverein, Ruderverein, Naturwissenschaftlicherverein i Turn-und Sport-Verein. Należały tutaj również: Ruder-Verein „Amicitia” (Schiller-Real Gymnasium); Musik-Verein oraz Ruder-Club „Borussia” (König Wilhelm-Gymnasium); Lese und Musik Verein Eintracht” (Friedrich Wilhelms Schule); Turn-Verein oraz Ruder Club (Stadtgymnasium), Leseverein (Bismarck Oberrealschule). Zob. Archiwum Państwowe w Szczecinie (APSz), sygn. 1480, Gimnazjum Mariackie w Szczecinie (Marienstiftsgymnasium in Stettin). 
zainteresowań. Dopiero jednak porównanie ich z materiałem aktowym pozwala na uzyskanie w miarę pełnego obrazu tego wycinka szkolnego życia. Przydatne dla omawianego tematu będą „Akta administracji szkolnej” przechowywane w Archiwum Państwowym w Szczecinie, zawierające działy: administracja ogólna, organizacja szkolnictwa, programy nauczania i plany lekcji, podręczniki i materiały pomocnicze, statystyka, obchody świąt i rocznic, związki polityczne i sportowe w szkołach, udział uczniów w różnych stowarzyszeniach w tym czytelniczych ${ }^{6}$.

Kluczowym elementem bazy źródłowej są akta Gimnazjum Mariackiego w Szczecinie. Archiwalia dotyczące administracji ogólnej, nauczania, biblioteki i innych typów zbiorów, spraw uczniowskich, budynku i wyposażenia sal, czy stowarzyszeń szkolnych, dostarczają cennego materiału do badań działalności tej placówki.

Nieocenione pozostają kroniki towarzystwa czytelniczego z lat 20. i 30. XX w. przechowywane w Archiwum Państwowym w Szczecinie ${ }^{8}$. Oprócz informacji organizacyjnych dotyczących zmieniającego się w kolejnych latach składu członków i zarządu, fotografii z przygotowanych przedstawień teatralnych, nazwisk i adresów przedstawicieli szczecińskich elit zapraszanych na szkolne przedstawienia (Verzeichniss der ,,Alten Herren”), znajdziemy tu sporo informacji pozwalających prześledzić większość podejmowanych inicjatyw, co ważneprzedstawionych $\mathrm{w}$ nieco innym świetle niż w drukowanych sprawozdaniach. Okazuje się bowiem, iż praca w kole nastręczała wiele trudności. Często odnotowywano na zebraniach znaczną absencję członków, imprezy przynosiły straty finansowe, a salę przeznaczoną na spotkania literackie wykorzystywały osoby nieuprawnione, co prowadziło do antagonizmów z dyrekcją szkoły 9 . Ta ostatnia niejednokrotnie też surowo oceniała popisy uczniów, krytykując ich np. za: „zbyt słabo wyuczony tekst"10. Na krytyczne uwagi odpowiadano, iż występujący osiągnęli to, co można było osiągnąć za pomocą dostępnych im środków ${ }^{11}$.

Omawiane tu Towarzystwo Czytelnicze w świetle przytoczonej literatury przedmiotu jawi się jako ważny komponent szkolnej rzeczywistości, będący

6 APSz, Kolegium Szkolne Prowincji Pomorskiej w Szczecinie (Provinzialschulkollegium für die Provinz Pommern in Stettin) 1815-1945.

7 APSz, Gimnazjum Mariackie w Szczecinie, 1642-1942. Sporo materiałów dotyczących Gimnazjum Mariackiego zachowało się także w zbiorach rękopiśmiennych Książnicy Pomorskiej w Szczecinie.

8 Zob. APSz, sygn. 1480, Gimnazjum Mariackie w Szczecinie, Chronik des Lese-Vereins am Marienstifts-Gymnasium zu Stettin von Ostern 1921 bis Ostern 1928; tamże, sygn. 1481, Chronik des Lese-Vereins am Marienstifts-Gymnasium zu Stettin 1928-1933.

9 Tamże.

10 APSz, sygn. 1480, Gimnazjum Mariackie w Szczecinie, Chronik des Lese-Vereins..., bez paginacji.

11 Tamże. 
nie tylko uzupełnieniem dydaktyki, ale też nośnikiem społecznej edukacji. Wart podkreślenia jest również fakt, iż jego historia sięga XVIII w. W latach 1751-1753 uczniowie Gimnazjum Mariackiego powołali koło czytelnicze Redner- und Dichtergesellschaft zu Stettin. Głównym jego celem sformułowanym w statucie było kultywowanie ojczystego języka, osobisty rozwój, budowanie poczucia wspólnoty, kształtowanie odpowiednich postaw, w tym gotowości do zmian $^{12}$.

W XIX w. pojawiły się w szkole nowe koła zainteresowań. Oprócz regularnych chórów powstawały towarzystwa integrujące śpiew chóralny i recytacje bądź stanowiące autonomiczne kółka czytelnicze. W historii szkoły zapisało się - działające długie lata - towarzystwo śpiewacze Pater-Verein ${ }^{13}$ zawdzięczające swoją nazwę pseudonimowi nauczyciela Hermanna Günthera Grassmanna (1809-1877), zwanego przez uczniów „Pater”14.

Jego uzupełnieniem było koło recytatorskie (Redeverein), którego członkowie popularyzowali literaturę antyczną i poezję współczesną ${ }^{15}$. Obydwa towarzystwa, sięgające swymi początkami 1831 r., wiążą się z inicjatywą profesora Carla Gottfrieda Scheiberta (1803-1898), który postanowił powołać te organizacje mając na uwadze integrację uczniów oraz ich rozwój artystyczny i duchowy ${ }^{16}$. W 1840 r., po odejściu Scheiberta, towarzystwo śpiewacze wykonujące muzykę kościelną i świecką podupadło, znacznie też zmalała liczba jego członków ${ }^{17}$.

12 Towarzystwo to liczyło sześciu członków, którzy w trakcie cotygodniowych spotkań omawiali nowo opublikowane artykuły oraz prezentowali własne prace. Jego działalność była rozmaicie oceniana. Johann Carl Conrad Oelrichs (1722-1799), historyk i bibliograf, profesor prawa w Gimnazjum Akademickim w Szczecinie pisał o Redner-und Dichtergesellschaft, iż: „sie aus erheblichen Ursachen dem Gymnasio mehr schädlich, als nützlich gewesen sei”, cyt. za M. Wehrmann, Festschrift zum dreihundertfünfzigjährigen..., s. 117. Cytat ten posłużył jako tytuł artykułu Andreasa Erba, w którym autor rozważał zawartą tu kwestię szkód i korzyści wynikających dla gimnazjalistów z przynależności do towarzystwa. Zob. A. Erb, „Dem Gymnasio mehr schädlich, als nützlich gewesen”? - Die „Redner- und Dichtergesellschaft zu Stettin” (1751-1753), „Baltische Studien” 2010, Bd. 96 , s. $67-80$.

13 O. Calliebe, 100 Jahre Pater-Verein, Stettin 1931.

14 H.G. Grassmann po ukończeniu edukacji w Gimnazjum Mariackim w Szczecinie, podjął studia teologiczne na uniwersytecie w Berlinie. Po powrocie do Szczecina rozpoczął pracę pedagogiczną, skupiając się na przedmiotach ścisłych. Jednocześnie prowadził badania w tym zakresie, publikując m.in. prace dotyczące rachunku różniczkowego. Grassmann zasłynął również jako wybitny językoznawca. Zob. „Allgemeine Deutsche Biographie” 1879, Bd. 9, s. 595-598.

15 W. Steffen, Das Stettiner Gymnasium um 1848, Marburg-Lahn 1957, s. 83, $236-237$.

16 Löwe's Bedeutung für Stettin. Vorgetragen im Saal der Loge am 1. December 1866 von Ludwig Giesebrecht, Stettin 1866, s. 14-15. C.G. Scheibert (1803-1898) studiował filologię i teologię na uniwersytecie w Greifswaldzie. Od 1829 r. nauczyciel w Gimnazjum Mariackim w Szczecinie. W 1840 r. Scheibert otrzymał stanowisko dyrektora w szkole im. Fryderyka Wilhelma (Friedrichs Wilhelms Schule). Po wyjeździe ze Szczecina kontynuował pracę pedagogiczną we Wrocławiu. Zob. „Allgemeine Deutsche Biographie” 1907, Bd. 53, s. 738-740; W. Steffen, dz. cyt.

17 W. Steffen, dz. cyt., s. 237. 
Ważną datą w historii szkolnego ruchu stowarzyszeniowego był rok 1849, kiedy to profesor Ludwig Giesebrecht przy wsparciu profesora Ferdinanda Calo założył Gesang- und Redeverein, którym kierował przez kolejne pięć lat ${ }^{18}$. Jego członkowie, mający w repertuarze m.in. dramat Atalia Racine’a, Obóz Wallensteina Schillera, sceny z Szekspira, Moliera i Goethego, prezentowali się w auli szkolnej przed licznie zgromadzonymi słuchaczami. Utwory wybranych autorów były deklamowane, zaprzestano bowiem wystawiania właściwych inscenizacji teatralnych ${ }^{19}$.

$\mathrm{Z}$ biegiem czasu piętrzące się trudności oraz brak dobrej woli ze strony dyrekcji przyczyniły się do rezygnacji Giesebrechta i znacznego osłabienia działalności założonego przez niego towarzystwa.

Przełomowym dla koła recytatorskiego był rok 1878. Powołano wówczas Leseverein, którego opiekunem został profesor Karl Conradt ${ }^{20}$. Było ono postrzegane jako nowy strażnik starej, oświeceniowej jeszcze tradycji, sięgającej wspomnianego wyżej Redner- und Dichtergesellschaft zu Stettin. W 1928 r., z okazji 50. rocznicy jego powstania, wystawiono w szkole tragedię Sofoklesa Król Edyp w thumaczeniu Waltera Amelunga (1865-1927). Osoba tłumacza nie była tutaj przypadkowa. Amelung był bowiem dawnym uczniem Gimnazjum Mariackiego i członkiem szkolnego koła recytatorskiego. Po ukończeniu gimnazjum podjął on studia aktorskie i próbował swoich sił na scenach w Monachium i Berlinie. Jak możemy przypuszczać - szlify aktorskie zdobywał w gimnazjalnym kole czytelniczym, biorąc udział w szkolnych inscenizacjach.

18 „Bericht über das Schuljahr 1927/28 - Marienstifts-Gymnasium mit Real-Gymnasium in der Entwicklung" 1928, s. 17, 20. Heinrich L. Theodor Giesebrecht (1792-1873) studiowat na uniwersytecie w Greifswaldzie. Od 1816 r. pracował w Królewskim i Miejskim Gimnazjum w Szczecinie (Vereinigtes Königliches und Stadt-Gymnasium). W 1826 r. uzyskał tytuł profesorski. Był aktywnym członkiem Towarzystwa Historii i Starożytności Pomorza (Gesellschaft für Pommersche Geschichte und Alterthumskunde in Stettin), gdzie prowadził badania nad słowiańszczyzną. Pozostawił też spuściznę literacką. Zob. E. Wendt, Stettiner Lebensbilder, Köln-Weimar-Wien 2004, s. 181-183; Friedrich F. Georg Calo (1814-1872) po ukończeniu szkoły średniej studiował w Berlinie teologię, filozofię i filologię. Po powrocie do Szczecina rozpoczął pracę pedagogiczną w szczecińskich szkołach. W latach 1840-1855 podróżował po Europie i Bliskim Wschodzie. Zdobyte doświadczenia wykorzystywał w pracy pedagogicznej. Zgromadził bogatą bibliotekę, zasobną m.in. w druki muzyczne, jako że muzykę i śpiew chóralny uważał za nieodłączny element wykształcenia młodzieży. Zob. M. Mazikiewicz, Muzyczna biblioteka profesora Calo, „Bibliotekarz Zachodniopomorski” 2010, nr 2-3, s. 12.

19 Löwe's..., s. 15.

20 K. Ludwig Ferdinand Conradt (1847-1922) po ukończeniu szkoły średniej w rodzinnym Koszalinie, studiował filologię klasyczną i germańską na uniwersytetach w Greifswaldzie i Berlinie. Po uzyskaniu uprawnień do nauczania w szkołach gimnazjalnych, rozpoczął pracę pedagogiczną, początkowo w Szczecinie, a następnie w Sławnie (Schlawe). Po powrocie do Szczecina zatrudnił się w Gimnazjum Mariackim. W 1889 r. objął stanowisko dyrektora gimnazjum w Gryficach. Był autorem rozpraw naukowych poświęconych dramatowi klasycznemu. Zob. B. Hitz, Die Direktoren des Greifenberger Friedrich-Wilhelms-Gymnasiums, „Beiträge zur Greifenberg - Treptower Geschichte” 2001, Jg. 24. s. 42-51. 
Z pewnością bywał też wraz z innymi członkami koła na przedstawieniach szczecińskiego Teatru Miejskiego. Oprócz aktorstwa studiował archeologię klasyczną na uniwersytetach w Tybindze, Lipsku i Monachium, i ostatecznie tej dziedzinie pozostał wierny, zapisując się w jej dziejach jako wybitny badacz. Na jego dorobek twórczy składają się również tłumaczenia literatury antycznej, m.in. dramatów Sofoklesa. Wspomniany przekład Króla Edypa, tłumacz zadedykował profesorowi Conradtowi, który w szczecińskim gimnazjum odkrył przed zdolnym wychowankiem antyczną poezję i dramat ${ }^{21}$.

Fot. 1. Afisz szczecińskiego Teatru Miejskiego z 1859 r., informujący o wolnym wstępie na przedstawienie dla uczniów szczecińskich szkół.

Źródło: biblioteka APSz, sygn. 11036. Zdjęcie: Anna Cichy

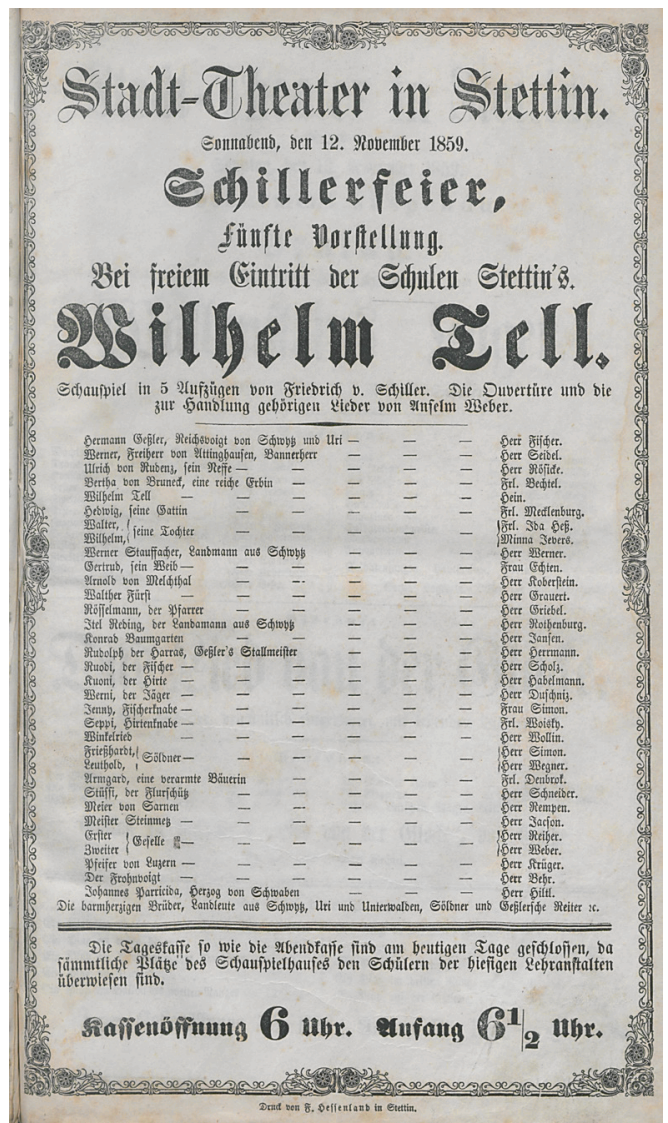

21 Zob. „Neue Deutsche Biographie” 1953, Bd. 1, s. 245; C.Z. Gałczyńska, Walther Amelung (1865-1927), mistrz identyfikacji i rekonstrukcji rzézby greckiej, „Meander. Rocznik poświęcony kulturze świata antycznego" 2013, t. 68, s. 133-177. 
Fot. 2. Zdjęcie z przedstawienia teatralnego Król Edyp przygotowanego z okazji 50-lecia istnienia Towarzystwa Czytelniczego w Gimnazjum Mariackim, marzec 1928 r. Źródło: APSz, Gimnazjum Mariackie, sygn. 1480. Zdjęcie: Anna Cichy

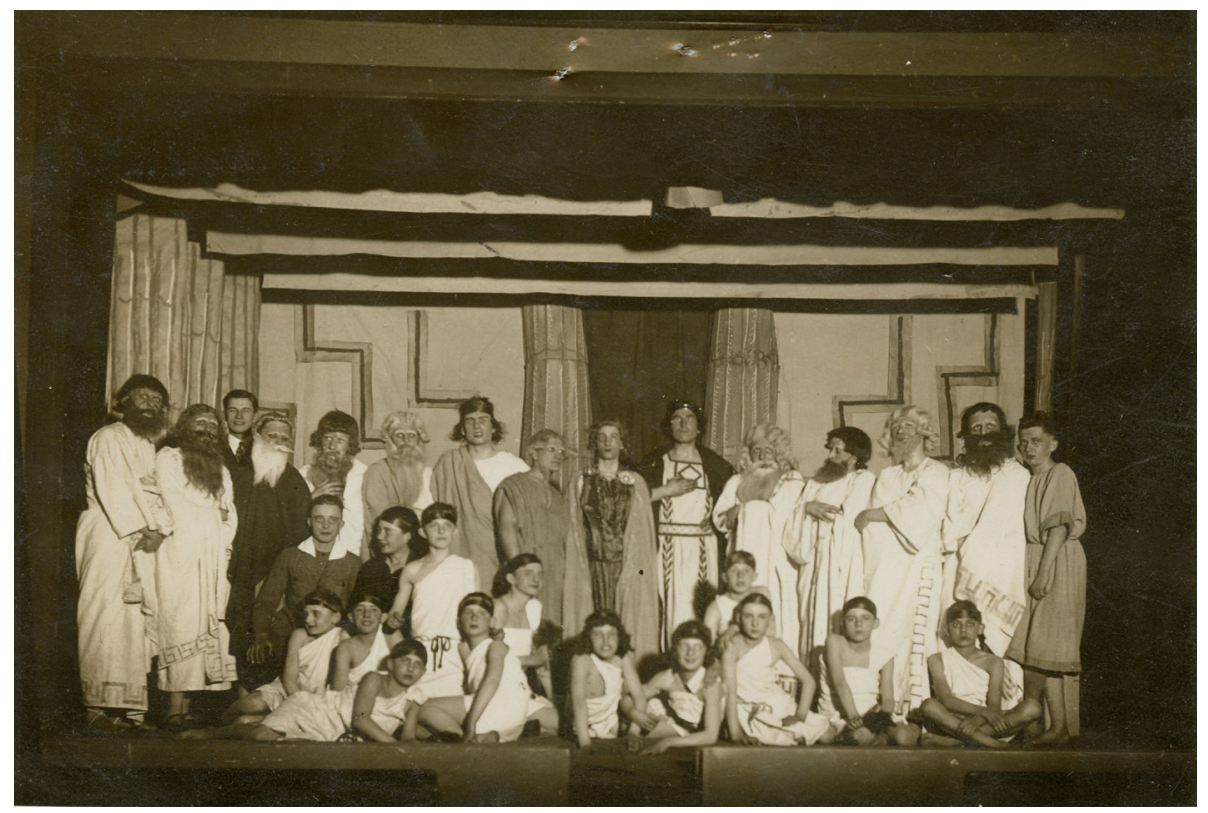

Na przestrzeni dziesięcioleci zmieniały się nazwy i program działania towarzystwa mającego na celu popularyzację książki i czytelnictwa. Pod koniec XIX w., występuje ono pod nazwą Deklamations-Verein der Gymnasiasten. Funkcjonowało również jako Gesang-und Deklamationsverein i Musik- und Leseverein $^{22}$. Jak wskazuje nazwa - recytacje łączono z występami wokalnymi. Programy muzyczno-dramatyczne odbywały się częstokroć poza murami szkonymi. Gościny udzielał uczniom m.in. szczeciński Dom Koncertowy, co, zważywszy na rangę tej instytucji, może świadczyć o pewnym prestiżu, jakim cieszyły się szkolne organizacje w lokalnym środowisku ${ }^{23}$. Swoje podwoje udostępniały gimnazjalistom również inne szczecińskie instytucje i stowarzyszenia. Miejsca, w jakich prezentowali się członkowie koła poza szkołą,

22 „Programm des Königl. Marienstifts-Gymnasiums zu Stettin für das Schuljahr von Ostern 1893 bis Ostern 1894” 1894, Progr. Nr. 143, s. 12; „Programm des Königl. Marienstifts-Gymnasiums zu Stettin für das Schuljahr von Ostern 1902 bis Ostern 1903” 1903, Progr. Nr. 170, s. 26.

23 „Programm ... von Ostern 1902 bis Ostern 1903”, s. 26, oraz „Programm des Königl. Marienstifts-Gymnasiums zu Stettin für das Schuljahr von Ostern 1913 bis Ostern 1914” 1914, Progr. Nr. 220, s. 15. Szczeciński Dom Koncertowy (Konzerthaus) powstał w 1884 r. Oprócz koncertów, w których brali udział sławni soliści krajowi i zagraniczni, odbywały się tu kongresy, odczyty, sesje naukowe. Zob. Encyklopedia Szczecina. T. 1: A-O, Szczecin 1999, s. 195-196. 
to Stowarzyszenie Abendhale, hotel Preussenhof, Hala Centralna i obiekty rekreacyjne nad jeziorem Rusałka ${ }^{24}$.

W hotelu Preussenhof w 1925 r. w trakcie dorocznego Winterfest, występy młodzieży z Leseverein oklaskiwało około 350 widzów. Była to rekordowa frekwencja, jakiej nie udało się powtórzyć w kolejnych latach ${ }^{25}$. Próby scen dramatycznych organizowano również w plenerze. Najchętniej uczęszczanym miejscem była podszczecińska Puszcza Bukowa ${ }^{26}$. Przedstawienia, zwłaszcza te odbywające się poza szkołą, bywały biletowane. W roku szkolnym 1914/1915 przygotowane przez uczniów inscenizacje Obóz Wallensteina i Rütlischwur przyniosły dochód w wysokości 100 marek $^{27}$.

Towarzystwo czytelnicze Gimnazjum Mariackiego, co podkreślano w sprawozdaniach szkolnych, wyróżniało się szczególnie na tle innych kół zainteresowań, stając się niejako ich wizytówką̨ ${ }^{28}$. Fakt ten nie może dziwić, zważywszy na liczne formy działalności, wśród których wyliczymy: Deklamationsstunde, Abenduterhaltung, Bunterabend, Alt-herren-abend, Elternabend ${ }^{29}$.

W ramach Abendunterhaltung i Bunterabend odbywały się popisy muzyczne i inscenizacje, w których jako widzowie uczestniczyli rodzice i krewni uczniów.

24 Abendhalle było to stowarzyszenie założone w $1836 \mathrm{r}$. w celu integracji rodzin kupieckich i konsulów rezydujących w Szczecinie. Zob. Gesetze der Abend-Halle, Stetttin den 17. September 1836, Stettin 1836. Hala sportowo-widowiskowa (Zentrallhallen) została wzniesiona w 1889 r., mogła pomieścić 2000 widzów. Dysponowała też mniejszymi salami. Dla gości przeznaczone były restauracje, kawiarnie i sale bilardowe. Zob. Encyklopedia Szczecina, T. 1, s. 323-324. Hotel Preussenhof został wybudowany pod koniec XVIII w. Był jednym z najnowocześniejszych hoteli w Niemczech. Tamże s. 361-362.

25 APSz, Gimnazjum Mariackie w Szczecinie, sygn. 1480, Chronik des Lese-Vereins..., s. 108.

26 „Königliches Marienstifts-Gymnasium zu Stettin. Oster-Program 1886” 1886, Progr. Nr. 128, s. 26.

27 „Jahresbericht des Königl. Marienstifts-Gymnasiums zu Stettin für das Schuljahr von Ostern 1914 bis Ostern 1915” 1915, Progr. Nr. 221, s. 17.

28 W Gimnazjum Mariackim, jak już wspominano, działało wiele kół zainteresowań. Trzeba podkreślić, iż niektóre z nich cieszyły się wielką popularnością. Dotyczyło to zwłaszcza towarzystw o profilu turystyczno-sportowym. Ożywioną działalność prowadził klub wioślarski (Ruder Verein) założony w 1908 r., w którym swoje zainteresowania mogli rozwijać uczniowie nastawieni na kulturę fizyczną i turystykę. Młodzież zrzeszona w szkolnym klubie wioślarskim uczestniczyła w zajęciach, które łączyły aktywność fizyczną z jednoczesnym poznawaniem zabytków i walorów turystycznych odwiedzanych miejsc. Zob. „Bericht über das Schuljahr 1924/25 Marienstifts-Gymnasium mit Real-Gymnasium in der Entwicklung" 1925, s. 14. W podobnym duchu działał klub sportowy (Turn-und Sportverein), założony w 1921 r., organizujący ćwiczenia lekkoatletyczne i inne gry sportowe. Koło przyrodnicze (Die Naturwissenschaftliche Vereinigung), którego początki sięgają 1911 r., skupiało uczniów zainteresowanych naukami przyrodniczymi. Jego członkowie uczestniczyli w wykładach i wycieczkach krajoznawczych. Zob. „Jahresbericht des Königl. Marienstifts-Gymnasiums zu Stettin für das Schuljahr von Ostern 1914 bis Ostern 1915” 1915, Progr. Nr. 221, s. 17. Najmniej członków liczyło zazwyczaj Towarzystwo uczniów abstynentów (Ein Bund enthaltsamer Schüler) powołane w 1919 r. organizujące m.in. pogadanki na temat szkodliwości palenia tytoniu i spożywania alkoholu. Zob. „Bericht über das Schuljahr 1925/26 Marienstifts-Gymnasium mit Real-Gymnasium in der Entwicklung” 1926, s. 15.

29 „Bericht über das Schuljahr 1929/30 Marienstifts-Gymnasium und Real-Gymnasium” 1930, s. 20. 
Deklamationsstunde z kolei były okazją do popisania się recytatorską wirtuozerią. Prezentowany repertuar był dość zróżnicowany, aczkolwiek największą popularnością cieszyły się komedie. Widzowie doceniali komizm sytuacyjny i dowcipny dialog. Często więc sięgano po utwory francuskiego komediopisarza Eugena Labicha (1815-1888), jak też angielskie jednoaktówki w niemieckich thumaczeniach ${ }^{30}$. Na organizowane przez towarzystwo imprezy artystyczne zapraszał zarząd, posiadający dokładną listę adresową osób, wśród których oprócz rodzin uczniów i przedstawicieli innych szkół dominowały szczecińskie elity świata kultury i gospodarki ${ }^{31}$.

Opiekunami koła czytelniczego byli na przestrzeni lat profesorowie legitymujący się dorobkiem literackim i naukowym ${ }^{32}$. Ich udział polegał m.in. na wyborze lektur oraz nadzorze nad przygotowywanymi inscenizacjami teatralnymi. Towarzystwa czytelnicze funkcjonowały w większości szkół i były podobnie zorganizowane. Ich członkowie spotykali się na cotygodniowych Lesestunden (godziny głośnego czytania), podczas których oprócz lektury wybranego tekstu z podziałem na role, omawiano sylwetki autorów, ich dorobek, akcentowano szczególne zalety prezentowanych dzieł. Taki uzupełniający komentarz nauczyciela miał przygotowywać uczniów do przyszłych, samodzielnych wyborów czytelniczych, już po zakończeniu edukacji szkolnej. Godziny głośnego czytania były też okazją do upamiętnienia rocznic narodzin i śmierci wybitnych pisarzy.

Działalność mariackiego Leseverein jest porównywalna z innymi kółkami czytelniczymi, jakich nie brakowało w szczecińskich szkołach. Typową formą ich aktywności były wspomniane Lesestunden. Erwin Ackerknecht dyrektor szczecińskiej Biblioteki Miejskiej (Stadtbibliothek), wielki orędownik tej formy pracy bibliotecznej pisał: [...] ci którzy przychodzą na godziny głośnego czytania, ujawniają w ten sposób wewnętrzną potrzebę literackiego uszlachetnienia [...] Najmilszym doświadczeniem związanym z głośnym czytaniem były chwile gdy mogłem stwierdzić, że teksty słyszane podczas tych godzin, ich uczestnicy odczytywali potem $\mathrm{w}$ gronie rodziny i przyjació ${ }^{33}$.

30 APSz, Gimnazjum Mariackie w Szczecinie, sygn. 1480, Chronik des Lese-Vereins...; tamże, sygn. 1481, Chronik des Lese-Vereins...

31 APSz, Gimnazjum Mariackie w Szczecinie, sygn. 1480, Chronik des Lese-Vereins...

32 Jednym z nich był Heinrich Viktor Emil Walter (1851-1926) - niemiecki archeolog. W latach 1875-1877 nauczyciel w gimnazjum w Salzwedel, następnie na przełomie lat 1877/1878 w gimnazjum w Koszalinie. W latach 1878-1921 pracował w Gimnazjum Mariackim w Szczecinie. Jak wielu innych profesorów tej szkoły był członkiem Towarzystwo Historii i Starożytności Pomorza w Szczecinie (Gesellschaft für Pommersche Geschichte und Altertumskunde in Stettin). Jego zainteresowania prehistorią Pomorza zaowocowały publikacjami na temat pomorskich zabytków archeologicznych i prac wykopaliskowych prowadzonych na terenie Pomorza Zachodniego. Zob. Geheimrat Dr. Emil Walter, „Monatsblätter” 1926, Jg. 40, Nr. 8/9, s. 29.

33 Erwin Ackerknecht-bibliotekarz, humanista (1880-1960). Wybór pism, [kol. red. L. Bąbolewski i in.], Szczecin 2007, s. 102-103. 
Omawiane koło czytelnicze miało w repertuarze swoich Lesestunden m.in. Oresteje Ajschylosa, Kupca weneckiego Szekspira, Dzika kaczkę Ibsena. Godziny głośnego czytania upływały też na lekturze: Goethego, Schillera Kleista, Strindberga, Hauptmanna, Kaisera, Klabunda ${ }^{34}$.

Towarzystwo organizowało corocznie loterie, z których dochód był przeznaczony na cele charytatywne. Aktywiści Leseverein jako fanty loteryjne fundowali oprócz książek, których było najwięcej - reprodukcje rycin, czekoladę, papierosy i likier śliwkowy. Wśród ofiarowanych na loterię wydawnictw można wymienić książki: Roseggera, Kleista, Storma, Maeterlincka, Ganghofera ${ }^{35}$.

By przygotowana oferta była atrakcyjna nie tylko treściowo, ale i formalnie uczniowie zrzeszeni w Leseverein korzystali z wypożyczalni kostiumów, perukarni i pomocy profesjonalnych muzyków.

Fot. 3. Reklama szczecińskiej wypożyczalni kostiumów z której korzystali uczniowie Gimnazjum Mariackiego przygotowujący inscenizacje teatralne Źródło: biblioteka APSz, sygn. P 269. Zdjęcie: Anna Cichy

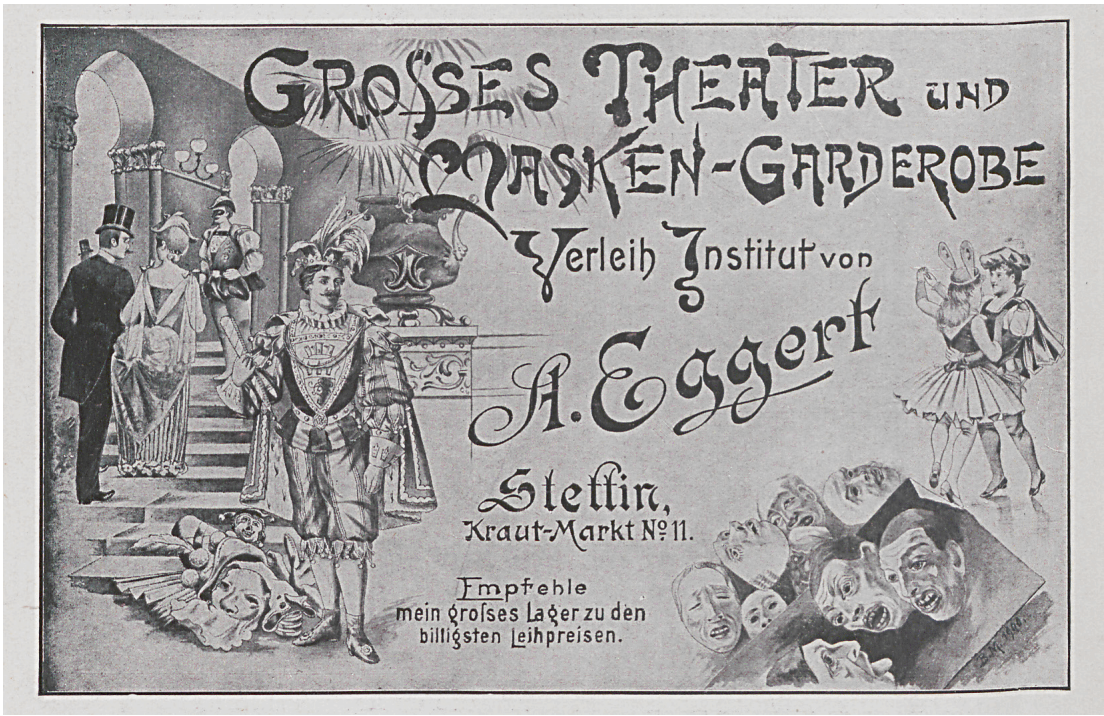

Dyrektorzy szczecińskich szkół, mając na uwadze pielęgnowanie poczucia wspólnoty środowiska uczniowskiego, chętnie popierali działalność szkolnych stowarzyszeń oraz szkolnej biblioteki, aczkolwiek niektórzy z nich widzieli tu pewne niebezpieczeństwa. W szkole im. Fryderyka Wilhelma (Friedrich-Wilhelms Schule) zastanawiano się np., w jaki sposób biblioteka uczniowska

34 APSz, Gimnazjum Mariackie w Szczecinie, sygn. 1480, Chronik des Lese-Vereins...; tamże, sygn. 1481, Chronik des Lese-Vereins...

35 Tamże. 
mogłaby integrować uczniów, „skoro czytanie bardziej izoluje niż łączy”36. Uznawano natomiast, iż łączyć mogą szkolne kółka zainteresowań, promując postawy koleżeństwa i współpracy. Przez 50 lat istnienia tej szkoły funkcjonowało tu wiele kółek, w których pokładano nadzieję na budowanie wspólnoty. Kółko literacko-muzyczne organizujące wykłady, godziny głośnego czytania i ćwiczenia muzyczne nosiło znamienną nazwę Eintracht (Jedność). Okazało się jednakże, iż nauczyciele nie zawsze mieli dobre doświadczenia z kółkami zainteresowań. W 1848 r. powstał w szkole Fryderyka Wilhelma klub demokratyczny, który wkrótce został zlikwidowany. Karom podlegały stowarzyszenia propagujące np. gry karciane. Tymczasem w szkolnych kołach zainteresowań upatrywano swego rodzaju środka zaradczego, mającego umacniać młodzież w dyscyplinie i dobrych obyczajach ${ }^{37}$.

Fot. 4-5. Rękopiśmienne kroniki Towarzystwa Czytelniczego Gimnazjum Mariackiego w Szczecinie: Chronik des Lese-Vereins

am Marienstifts-Gymnasium zu Stettin von Ostern 1921 bis Ostern 1928;

Chronik des Lese-Vereins am Marienstifts-Gymnasium zu Stettin 1928-1933.

Źródło: APSz, Gimnazjum Mariackie w Szczecinie, sygn. 1480; 1481. Zdjęcie: Anna Cichy
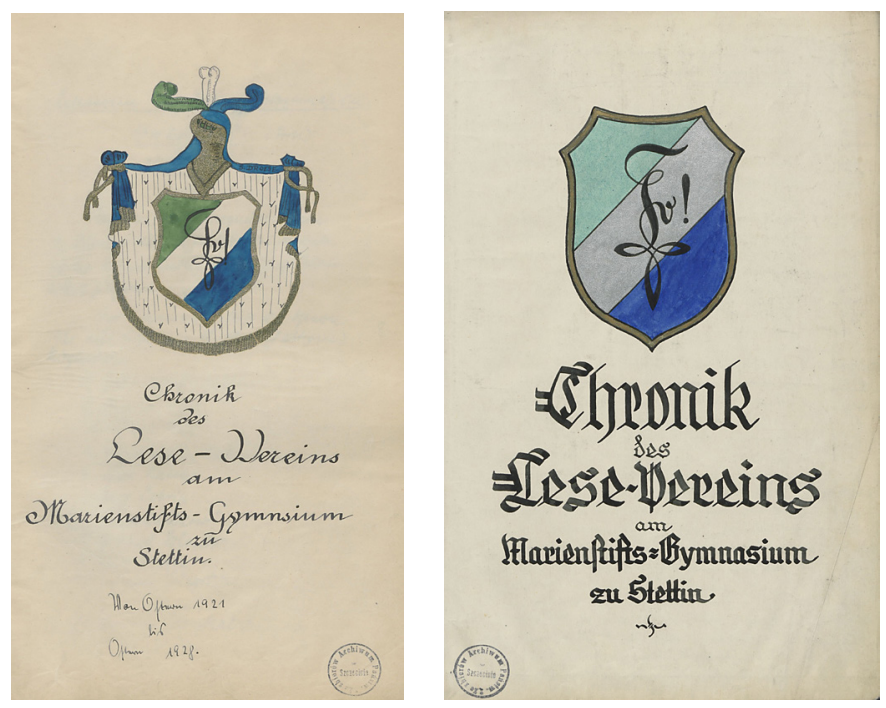

Niektóre z gimnazjalnych towarzystw organizowały niewielkie księgozbiory, sprofilowane pod kątem prowadzonej działalności. Trzeba w tym miejscu zaznaczyć, iż jedna biblioteka szkolna należała do rzadkości. Biblioteki

36 Festschrift zur Feier des 50jährigen Jübilaums der Friedrich-Wilhelms Schule zu Stettin, Stettin 1890, s. 32.

37 Tamże, s. 33. 
szkolne działające na wszystkich szczeblach oświaty szkolnej, dzieliły się zazwyczaj na nauczycielskie i uczniowskie. W bibliotekach uczniowskich wyodrębniano dodatkowo mniejsze jednostki organizacyjne, jak biblioteki klasowe, podręczne, fachowe, podręczników, pracowni, kółek zainteresowań, organizacji i kolekcje zbiorów. Model taki określany bywa jako struktura klasowo-satelitarna ${ }^{38}$. I z takimi właśnie rozwiązaniami mamy do czynienia w Gimnazjum Mariackim w Szczecinie w którym w XIX i na początku XX w., funkcjonowały: Haupt-Bibliothek, Bibliotheca discipulorum Gymnasi, Seminar-Bibliothek, Schüler-Bibliothek, Arbeits-Bibliothek, Schulbücher-Sammlung, Unterstützung-Bibliothek (Bibliotheca Pauperum) ${ }^{39}$.

Biblioteki kółek zainteresowań były organizowane przez członków tych organizacji pod nadzorem opiekuna. Stanowiły niewielkie księgozbiory, sprofilowane pod kątem typowej dla kółka aktywności. W Gimnazjum Mariackim największą tego typu biblioteką dysponowało towarzystwo czytelnicze, którego zasób biblioteczny liczył ponad 300 pozycji, podczas gdy inne kółka zainteresowań posiadały po 50-60 egzemplarzy ${ }^{40}$. Księgozbiór towarzystwa czytelniczego ujęty był w rękopiśmiennym katalogu prowadzonym od $1907 \mathrm{r} .{ }^{41}$ W zawartym tu regulaminie bibliotecznym odnajdujemy uwagi świadczące

38 Festschrift zur Feier.., s. 32.

39 „Königliches Marienstifts-Gymnasium zu Stettin. Oster-Program 1886” 1886, Progr. Nr. 128, s. 29.

40 Wyjątek stanowiła biblioteka Koła przyrodniczego (Die Naturwissenschaftliche Vereinigung), która w pierwszych dekadach XX w. posiadała już ponad 130 woluminów. Zob. „Jahresbericht des Königl. Marienstifts-Gymnasiums zu Stettin für das Schuljahr von Ostern 1914 bis Ostern 1915" 1915, Nr. 221, s. 17.

41 APSz, Gimnazjum Mariackie w Szczecinie, sygn. 1482, Haupt-Katalog der Bibliothek Lese-Vereins. Katalogi zbiorów w bibliotekach szkolnych przybierały różne formy. W Gimnazjum Mariackim jedną z nich były spisy książek z poszczególnych dziedzin powielane hektograficznie, jak chociażby: Verzeichniss der Bücher aus den Fächern der Naturkunde und Mathematik welche sich in der Bibliothek des Gymnasii zu Stettin befinden, opracowany w 1837 r. przez profesora Grassmanna. Przyjętą formą były wspomniane rękopiśmienne katalogi, jak chociażby rejestr biblioteki pomocniczej z lat 20. i 30. odzwierciedlający przy okazji przemiany mentalności i przewartościowanie dawnych pojęć i treści, co szczególnie widoczne jest po 1933 r. Wśród nazwisk autorów lektur pojawia się wówczas wielu czołowych ideologów nazistowskich. Zob. APSz, Gimnazjum Mariackie w Szczecinie, sygn. 1369, Katalog der Hülfsbücherei 1926-1942, s. 35 i n. Podstawową odmianą były jednakże drukowane katalogi, które publikowano już w XIX w., by wymienić wydany w $1869 \mathrm{r}$. katalog biblioteki uczniowskiej, rejestrujący zasób w trzech działach: I. Historia II. Przyroda i etnologia oraz Literatura piękna z podziałem na klasy A: Prima, B: Secunda i Tertia, C: Quarta i Quinta. Zob. APSz, Gimnazjum Mariackie w Szczecinie, sygn. 1331, Katalog der Schüler-Bibliothek des Gymnasiums zu Stettin, Stettin 1869, bez paginacji. Z kolei pochodzący z 1912 r. katalog biblioteki uczniowskiej ujmował księgozbiór w 17 działach rzeczowych, w których książki uporządkowano według alfabetycznego spisu autorów. Publikację otwierało hasło: „Szanujcie książki. Są one powierzonym dobrem i jeszcze wielu po was powinny przynieść radość”. Zob. Bücherverzeichniss der Schülerbücherei. Beigabe zum Programm des Königl. Marienstifts- Gymnasiums zu Stettin, Stettin 1912. Formą promocji zbiorów były też katalogi ścienne w klasach, informujące o nowościach i piśmiennictwie z poszczególnych dziedzin wiedzy. 
o tym, iż regularnie przeprowadzano w tej placówce kontrolę zbiorów, odnotowując wszystkie braki oraz ubytki, przy których każdorazowo widniało nazwisko osoby dokonującej wykreślenia poszczególnych pozycji z katalogu. Był więc ów katalog swego rodzaju inwentarzem. Księga liczyła 351 wpisów numerowanych ${ }^{42}$.

Fot. 6. Pieczątka biblioteki Towarzystwa Czytelniczego

Gimnazjum Mariackiego w Szczecinie

Źródło: APSz, Gimnazjum Mariackie w Szczecinie, sygn. 1482. Zdjęcie: Anna Cichy

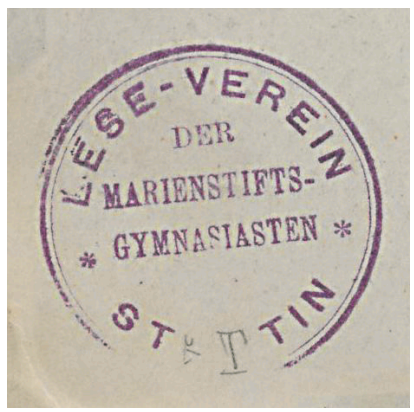

Zgodnie z regulaminem pierwsza szpalta katalogu zawierała numer porządkowy, w drugiej podawano autora, tytuł, miejsce i rok wydania. Niektóre opisy bywały jednak znacznie obszerniejsze. Przykładem może służyć powieść Ostatnie dni Pompejów, gdzie zaznaczono, iż jest to powieść historyczna, podano krótkie streszczenie, a nawet nazwisko ilustratora. Często podawano też liczbę dostępnych egzemplarzy. Biblioteka dysponowała zazwyczaj dziesięcioma egzemplarzami tego samego tytułu. Gromadzono przede wszystkim literaturę piękną, w której przeważały utwory dramatyczne, często wykorzystywane w trakcie godzin głośnego czytania. Stąd obecne tu dzieła dramaturga Ludwiga Fuldy (1862-1939), jak też wiele wydawnictw o tematyce satyrycznej, by wymienić Norberta Falka (1872-1932), autora antologii poświęconych literaturze humorystycznej. Występująca w tym zasobie jego publikacja Das Buch des Lachens. Eine Auswahl bester humoristischer Werke der Weltliteratur (Berlin 1912), to bogato ilustrowana księga zawierająca wybór najlepszych humorystycznych tekstów światowej literatury. Oprócz tego

42 W katalogu zamieszczone zostały również wskazówki dotyczące organizacji pracy. Ażeby biblioteka mogła funkcjonować według jednolitych zasad podano odnośne uwagi. Każda książka otrzymywała pieczątkę na odwrocie strony tytułowej oraz wypisaną ołówkiem sygnaturę umieszczaną w lewym dolnym rogu okładki. Egzemplarze włączano do księgozbioru na bieżąco. Książki nieoprawione lub uszkodzone trafiały do introligatorni. Katalog ten był przeznaczony wyłącznie dla bibliotekarza. Dla użytkowników miał być przygotowany oddzielny katalog alfabetyczny, który jak można przypuszczać nigdy nie powstał. Zob. APSz, Gimnazjum Mariackie w Szczecinie, sygn. 1482, Haupt-Katalog der Bibliothek..., s. 1-2. 
odnotowujemy w stowarzyszeniowej bibliotece nowele i powieści znanych i cenionych autorów, oraz takich twórców jak Gregor Samarow (1829-1903) piszący powieści przygodowe dla młodzieży. Pod względem chronologicznym największą grupę autorów stanowili przedstawiciele pokolenia literatów tworzących na przełomie XIX i XX w. Byli to twórcy znani i cenieni. Oprócz beletrystyki znalazły się w bibliotece Leseverein również dzieła naukowe i popularnonaukowe z historii literatury i krytyki literackiej, które dla aktywistów towarzystwa były z pewnością istotnym narzędziem ułatwiającym też wybór lektur i pomocą w kształtowaniu umiejętności dostrzegania zalet dobrej książki.

Omawiany katalog otwiera księga pamiątkowa Gimnazjum Mariackiego autorstwa Martina Wehrmanna. Wśród odnotowanych tu autorów znaleźli się m.in. Eduard Möricke, Edmondo de Amicis, Alexis Willibald, Artur Schnitzler, Theodor Fontane, Hermann Sudermann, Theodor Storm, Wolfgang Goethe, Walter $\operatorname{Scot}^{43}$.

Dla porównania w tabelce nr 1 zestawiono autorów biblioteki uczniowskiej Gimnazjum Mariackiego ${ }^{44}$.

Omawiane towarzystwo czytelnicze działało pod hasłem vivat - crescat - floreat (niech żyje, wzrasta, kwitnie). Jak wynika z analizy kronik nie zawsze udawało się je realizować. Pomimo tego trzeba stwierdzić, iż należało ono do wyróżniających się organizacji szkolnych. Aktywiści Leseverein poprzez swoje działania starali się popularyzować literaturę piękną, teatr, upowszechniać czytelnictwo. W ramach przyjętych zadań organizowali loterie, wycieczki do teatru, dawali przedstawienia dla mieszkańców. Tak więc ich wysiłek nie pozostawał bez wpływu na kształt kultury szkolnej, a miał też swój oddźwięk w mieście. Występy uczniów poza murami szkolnymi były niejednokrotnie odnotowywane na łamach szczecińskiej prasy. Trzeba podkreślić, iż działalność parateatralna uczniów była istotnym elementem integracji szkoły ze środowiskiem. Członkowie towarzystwa często też zaznaczali swój udział w przedsięwzięciach firmowanych przez władze miejskie, by przywołać organizowany w Niemczech w latach 20. XX w., „Tydzień książki”"45.

43 Tamże.

44 APSz, Gimnazjum Mariackie, sygn. 1331, Katalog der Schüler-Bibliothek... Warto dodać, iż księgozbiory szczecińskich bibliotek szkolnych, w tym omawianego tu koła czytelniczego, uległy rozproszeniu w czasie II wojny światowej i po jej zakończeniu.

45 „Bericht über das Schuljahr 1928/29 Marienstifts-Gymnasium mit Real-Gymnasium in der Entwicklung" 1929, s. 22 
Tab. 1. Zestawienie autorów i tytułów biblioteki uczniowskiej Gimnazjum Mariackiego.

\begin{tabular}{|c|c|}
\hline AUTOR & TYTUŁ \\
\hline \multirow{3}{*}{ Alexis Willibald } & Schloss Avalon \\
\hline & Kabanis \\
\hline & Der falsche Waldemar \\
\hline \multirow[t]{2}{*}{ Andersen Hans Christian } & Gesammelte Märche \\
\hline & Bulwer's sämmtliche Romane \\
\hline Calderon de la Barca & Schauspiele \\
\hline Campe Joachim Heinrich & Robinson der Jüngere \\
\hline Cervantes Savedra & Don Quichote von la Mancha \\
\hline \multirow{3}{*}{ Cooper James Fenimore } & Der Spion \\
\hline & Der letzte der Mohikaner \\
\hline & Die Steppe \\
\hline Eschenbach Wolfram von & Zwei Rittergedichte \\
\hline Freytag Gustav & Soll und haben \\
\hline Fröhlich Abraham Emanuel & 170 Fabeln \\
\hline \multirow{3}{*}{ Giesebrecht Ludwig } & Epische Dichtungen \\
\hline & Gedichte \\
\hline & Göthes Werke \\
\hline Grimm Jacob und Wilhelm & Kinder- und Hausmärchen \\
\hline \multirow{3}{*}{ Heyse Paul } & Die Blinden \\
\hline & Das Mädchen von Treppi \\
\hline & Marrion \\
\hline Klopstock Friedrich Gottlieb & Der Messias \\
\hline Gustav Nieritz & Erzählungen \\
\hline Richter Paul Friedrich & Sämmtliche Werke \\
\hline Seume Johan Gottfried & Gedichte \\
\hline Simrock Karl Joseph & Deutsche Märchen \\
\hline \multirow{2}{*}{ Scott Walter } & die Verlobten, \\
\hline & der Talisman \\
\hline Tasso Torquato & Befreites Jerusalem \\
\hline Uhland Ludwig & Gedichte \\
\hline
\end{tabular}

Źródło: APSz, Gimnazjum Mariackie, sygn. 1331, Katalog der Schüler-Bibliothek des Gymnasiums zu Stettin, Stettin 1869, bez paginacji 
Fot. 7. Strona tytułowa katalogu bibliotecznego

Towarzystwa Czytelniczego Gimnazjum Mariackiego w Szczecinie

Źródło: APSz, Gimnazjum Mariackie w Szczecinie, sygn. 1482. Zdjęcie: Anna Cichy

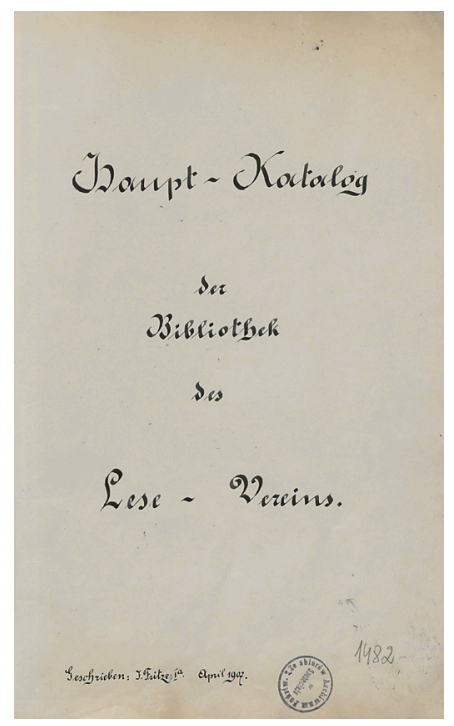

Działalność wspomnianych tutaj szkolnych kółek zainteresowań, nie została jak dotąd szerzej omówiona w literaturze. Dzięki zainicjowanej w 2016 r. w Książnicy Pomorskiej przez Agnieszkę Borysowską serii multidyscyplinarnych konferencji „Od Pedagogium Książęcego do Gimnazjum Mariackiego” istnieje szansa na wypełnienie luki w literaturze przedmiotu, bowiem ich pokłosiem są pokonferencyjne publikacje. Pierwsza z nich ukazała się w $2018 \mathrm{r}$.: Od Pedagogium Książęcego do Gimnazjum Mariackiego. Z dziejów szkolnictwa półwyższego w Szczecinie do poczatków XIX w. pod redakcją A. Borysowskiej (Szczecin 2018). Materiały z drugiej konferencji natomiast zostały opublikowane w „Przeglądzie Zachodniopomorskim” 2020 w zeszycie 2. Kluczowego materiału dostarczają archiwalia, pozwalające na szerszą perspektywę w spojrzeniu na szkołę i rozmaite segmenty jej działalności, w tym na szkolne koła zainteresowań. Obraz towarzystwa czytelniczego w świetle materiałów archiwalnych odbiega nieco od sposobu postrzegania zawartego w drukowanych rocznikach szkolnych. Temat o tyle również wart jest podjęcia, iż wpisuje się w szerszy kontekst niezbyt dobrze jak dotąd rozpoznanych szczecińskich teatrów szkolnych ${ }^{46}$.

46 M. Kozłowska, Teatry szkolne w Szczecinie XVII-XX wieku. Rekonesans, [w:] Regionalizm Pomorza Zachodniego od XIX do XXI wieku. Rekonesans, pod red. B. Ochendowskiej-Grzelak, Szczecin 2008, s. 47-64. 


\section{Bibliografia}

Archiwalia

Archiwum Państwowe w Szczecinie

- Zespół Gimnazjum Mariackie w Szczecinie (Marienstiftsgymnasium in Stettin): sygn. 1480, Chronik des Lese-Vereins am Marienstifts-Gymnasium zu Stettin von Ostern 1921 bis Ostern 1928;

sygn. 1481, Chronik des Lese-Vereins am Marienstifts-Gymnasium zu Stettin 1928-1933;

sygn. 1482, Haupt-Katalog der Bibliothek Lese-Vereins;

sygn. 1331, Katalog der Schüler-Bibliothek des Gymnasiums zu Stettin, Stettin 1869.

- Zespół Kolegium Szkolne Prowincji Pomorskiej w Szczecinie (Provinzialschulkollegium für die Provinz Pommern in Stettin) 1815-1945.

Opracowania i źródła drukowane

„Allgemeine Deutsche Biographie” 1879, Bd. 9.

„Allgemeine Deutsche Biographie” 1907, Bd. 53.

Akademicki Szczecin. XVI-XXI wiek, red. P. Niedzielski, W. Tarczyński, Szczecin 2016.

„Bericht über das Schuljahr 1924/25 Marienstifts-Gymnasium mit Real-Gymnasium in der Entwicklung" 1925.

„Bericht über das Schuljahr 1925/26 Marienstifts-Gymnasium mit Real-Gymnasium in der Entwicklung" 1926.

„Bericht über das Schuljahr 1927/28 - Marienstifts-Gymnasium mit Real-Gymnasium in der Entwicklung“ 1928.

„Bericht über das Schuljahr 1928/29 Marienstifts-Gymnasium mit Real-Gymnasium in der Entwicklung" 1929.

„Bericht über das Schuljahr 1929/30 Marienstifts-Gymnasium und Real-Gymnasium” 1930.

Bücherverzeichniss der Schülerbücherei. Beigabe zum Programm des Königl. Marienstifts- Gymnasiums zu Stettin, Stettin 1912.

Calliebe O., 100 Jahre Pater-Verein, Stettin 1931.

Encyklopedia Szczecina. T. 1: A-O, Szczecin 1999.

Engelsing R., Der Bürger als Leser, Lesergeschichte in Deutschland 1500-1800, Stuttgart 1974.

Erb A., „Dem Gymnasio mehr schädlich, als nützlich gewesen”? - Die „,Redner- und Dichtergesellschaft zu Stettin” (1751-1753), „Baltische Studien” 2010, Bd. 96, s. 67-80. Erwin Ackerknecht - bibliotekarz, humanista (1880-1960). Wybór pism, [kol. red. L. Bąbolewski i in.], Szczecin 2007.

Festschrift zur Feier des 50jährigen Jübilaums der Friedrich-Wilhelms Schule zu Stettin, Stettin 1890. 
Gałczyńska C.Z., Walther Amelung (1865-1927), mistrz identyfikacji i rekonstrukcji rzeźby greckiej, „Meander. Rocznik poświęcony kulturze świata antycznego” 2013, t. 68, s. $133-177$.

Geheimrat Dr. Emil Walter, „Monatsblatter” 1926, Jg. 40, Nr. 8/9, s. 29.

Gesetze der Abend-Halle, Stetttin den 17. September 1836, Stettin 1836.

Hitz B., Die Direktoren des Greifenberger Friedrich-Wilhelms-Gymnasiums, „Beiträge zur Greifenberg - Treptower Geschichte" 2001, Jg. 24, s. 42-51.

„Jahresbericht 1911/1912 des Stettiner Stadtgymnasiums ehemaligen Ratslyceums” 1912. „Jahresbericht des Königl. Marienstifts-Gymnasiums zu Stettin für das Schuljahr von Ostern 1914 bis Ostern 1915” 1915, Progr. Nr. 221.

„Königliches Marienstifts-Gymnasium zu Stettin. Oster-Program 1886” 1886, Progr. Nr. 128.

Kozłowska M., Teatry szkolne w Szczecinie XVII-XX wieku. Rekonesans, [w:] Regionalizm Pomorza Zachodniego od XIX do XXI wieku. Rekonesans, pod red. B. Ochendowskiej-Grzelak, Szczecin 2008, s. 47-64.

Löwe's Bedeutung für Stettin. Vorgetragen im Saal der Loge am 1. December 1866 von Ludwig Giesebrecht, Stettin 1866.

Mazikiewicz M., Muzyczna biblioteka profesora Calo, „Bibliotekarz Zachodniopomorski” 2010, nr 2-3, s. 6-47.

„Neue Deutsche Biographie” 1953, Bd. 1.

Od Pedagogium Książęcego do Gimnazjum Mariackiego. Z dziejów szkolnictwa pótwyższego w Szczecinie do początków XIX w., red. A. Borysowska, Szczecin 2018.

„Programm des Königl. Marienstifts-Gymnasiums zu Stettin für das Schuljahr von Ostern 1893 bis Ostern 1894” 1894, Progr. Nr. 143.

„Programm des Königl. Marienstifts-Gymnasiums zu Stettin für das Schuljahr von Ostern 1902 bis Ostern 1903” 1903, Progr. Nr. 170.

„Programm des Königl. Marienstifts-Gymnasiums zu Stettin für das Schuljahr von Ostern 1913 bis Ostern 1914” 1914, Progr. Nr. 220.

„Staatliches König- Wilhelmsgymnasium zu Stettin. Bericht über das Schuljahr 1927/1928” 1928.

Steffen W., Das Stettiner Gymnasium um 1848, Marburg-Lahn 1957.

Wehrmann M., Festschrift zum dreihundertfünfzigjährigen Jubiläum des Königlichen Marienstifts-Gymnasiums zu Stettin am 24. und 25. September 1894, Stettin 1894.

Wendt E, Stettiner Lebensbilde, Köln-Weimar-Wien 2004. 
